P-ISSN 2442-6636

E-ISSN 2355-3987

www.ijhn.ub.ac.id

Artikel Hasil Penelitian

\title{
The Comparison Effect of Small-quantity Lipid-based Nutrient Supplements and Biscuit on hemoglobin level of infants in Indonesia
}

\author{
Nurul Muslihah ${ }^{*}$, Ali Khomsan ${ }^{2}$, Hadi Riyadi², Dodik Briawan ${ }^{2}$ \\ 1*Program Studi Ilmu Gizi, Fakultas Kedokteran, Universitas Brawijaya, \\ ${ }^{2}$ Departemen Gizi Masyarakat, Fakultas Ekologi Manusia, Insitut Pertanian Bogor \\ *Alamat korespondensi: nurul_muslihah@yahoo.com, Tlp : +62341569117 ext 133
}

\begin{abstract}
Abstrak
Suplemen gizi berbasis lipid dosis kecil (SQ-LNS) yang diperkaya lemak dan kandungan vitamin dan mineral dapat memenuhi kekurangan asupan dan kebutuhan zat besi dan hal ini dapat berpotensi untuk mengurangi prevalensi anemia pada anak-anak. Tujuan penelitian ini untuk mengkaji dampak pemberian SQ-LNS dan biskuit terhadap kadar hemoglobin dan mengurangi kejadian anemia. Rancangan penelitian ini non-randomized controlled trial selama enam bulan pada 168 bayi yang menerima $20 \mathrm{~g} \mathrm{~S}$-LNS atau 3 keping biskuit atau tanpa intervention setiap hari. Kadar hemoglobin diukur pada awal penelitian, 3 dan 6 bulan setelah intervensi dengan hemocue autoanalyzer. Untuk membandingkan kadar hemoglobin menggunakan uji Linear Model ANCOVA dan uji regresi logistic untuk perbedaan insiden anemia. Pada kelompok SQ-LNS setelah 3 bulan intervensi, kadar hemoglobin meningkat secara signifikan sampai $0.73 \mathrm{~g} / \mathrm{dl}(p<0.05)$, prevalence anemia menurun sampai $19.5 \%$ dan signifikan menurunkan insiden anemia sampai $100 \%(p<0.05)$. Setelah 6 bulan intervensi, kadar hemoglobin meningkat secara signifikan sampai $0.15 \mathrm{~g} / \mathrm{dl}$, prevalensi anemia menurun sampai 5.6\% dengan menurunkan insiden anemia sampai $79 \%$. Pada kelompok Biscuit, setelah 3 bulan dan 6 bulan intervensi, kadar hemoglobin menurun sampai 0.17 $\mathrm{g} / \mathrm{dl}$ dan $0.36 \mathrm{~g} / \mathrm{dl}$ dengan prevalensi anemia meningkat dari $24.2 \%$ dan $17.8 \%$ dan juga menurunkan kejadian anemia sampai $63 \%$ dan $27 \%$. Pemberian SQ-LNS lebih efektif meningkatkan kadar hemoglobin dan mengurangi insiden anemia pada bayi usia 6-12 bulan setelah 3 bulan intervensi dibandingkan Biskuit.
\end{abstract}

Kata kunci: SQ-LNS, Biskuit, Hemoglobin, Anemia

\begin{abstract}
Small-quantity lipid-based nutrient supplements (SQ-LNS) with enriching fat and vitamin and mineral can fill the gap of iron intake and requirement as well as the potential for reducing the prevalence of anemia among childhood. The purpose of the study was to assess the impact of SQLNS and biscuit on hemoglobin concentrations and reducing of incidence anemia. A 6-month nonrandomized controlled trial was performed among 168 infants who received $20 \mathrm{~g}$ of LNS or 3 pieces biscuits or no intervention. Hemoglobin was measured at 0, 3, 6 months of intervention using hemocue autoanalyzer. To compare hemoglobin concentration using Linear Model ANCOVA and logistic regression for the difference in the incidence of anemia. In SQ-LNS group over three-
\end{abstract}


month intervention, the adjusted mean hemoglobin concentration increased a significantly by 0.73 $g / d l(p<0.05)$, the prevalence of anemia decreased by $19.5 \%$ and a significant reduction in the incidence of anemia by $100 \%$ ( $p<0.05$ ). Over six-month intervention, the adjusted mean hemoglobin concentration only increased significantly by $0.15 \mathrm{~g} / \mathrm{dl}$, the prevalence decreased by $5.6 \%$ with a reduction in the incidence of anemia by 79\%. In Biscuit group, over 3-month and 6month intervention, the hemoglobin concentration decreased by $0.17 \mathrm{~g} / \mathrm{dl}$ and $0.36 \mathrm{~g} / \mathrm{dl}$ with the prevalence of anemia was increased by $24.2 \%$ and $17.8 \%$ as well as reducing in the incidence of anemia by $63 \%$ and $27 \%$. SQ-LNS was more effective in improving hemoglobin level and reducing of incidence anemia among infant 6-12 months over three-months intervention than the biscuit.

Key words: SQ-LNS, biscuit, hemoglobin, anemia

\section{INTRODUCTION}

In the fact, 270 million children under the age of 5 years (270 million) are affected by anemia with the highest prevalence in developing countries [1]. Anemia during childhood is also a common public health problem in Indonesia. Basic Health Research 2013 reported that the prevalence of anemia among children 1259 months of age was $42.6 \%$ [2]. A survey in Bangkalan district, Indonesia, showed that the prevalence of anemia was $46.7 \%$ among children age 6 to 23 months old [3]. The prevalence of anemia decreased from $58.4 \%$ to $42.6 \%$ among children aged 6-11 months and 12-23 months. Anemia prevalence of $40 \%$ or more in any population is considered as a severe public health concern [4].

Anemia as a result of iron deficiency with a low concentration of hemoglobin has adverse functional consequences and may impair cognitive and motor development and cause fatigue and low productivity [5]. The cause of anemia due deficiencies of iron in young children are inadequate intake or poor absorption [6], and requirement is high at the start of life due to rapid growth, while their stores are low [7].

The period 6-24 months is an important phase because of children transition from breast milk to complementary food, as well as require high amounts of micronutrient relatively small quantities of foods to support growth and development. A breastfed infants at 6-8 months of age need more than 4 times of zinc density (per $100 \mathrm{kcal}$ of food) and 9 times of iron density than an adult male needed [8]. Vitta and Dewey (2012) have analyzed using linear programming of unfortified complementary food and indicated that there would be gaps in iron and zinc intakes and will be met with unrealistic amounts of liver that must be consume daily [9].

Currently, home fortification of complementary foods with multiple micronutrient powders (MNP) has been proven as effective as iron drops in improving hemoglobin status and reduction of anemia [10]. Apart from home fortification with MNP, small-quantity lipidbased nutrient supplements providing energy, protein, essential fatty acids, and micronutrients can be used as the food supplement to complement the diet and prevent potential deficiencies. Lipid-based nutrient supplements (LNS), which can be added to complementary food at the time of consumption, are designed to prevent undernutrition and to promote healthy growth and development [11].

Small-quantity lipid-based nutrient supplements (SQ-LNS) can fill gap iron intake and high needed as well as the potential for reducing the prevalence of anemia among childhood. In Indonesia, the provision biscuit MP-ASI used in supplementary feeding programs for children younger than five years old and still not yet for evaluating of effect both growth and anemia. 
The purpose of the study was to compare the effect of supplementation with SQ-LNS and fortified biscuits on the hemoglobin concentration among infants in a rural area, Indonesia. Sub-objectives included describing changes in the prevalence and incidence of anemia in the participants.

\section{METHODS}

\section{Study Design}

The study was conducted in 50 villages of eight sub-districts in Bangkalan Districts, West Madura Island, East Java Province, Indonesia between October 2014 and August 2015. A communitybased, non-randomized, controlled intervention was selected for the study design.

The study design was chosen due to the different type of product of intervention i.e., food supplement using peanut paste with multiple vitamin and mineral fortified and biscuit.

The study compared the effects of three groups schemes with small-quantity lipid-based nutrient supplements (SQLNS) in the form of fortified peanut-paste, Biscuit MP-ASI, and a control group. Infants in the control group were not provided with any complementary food supplement during the study period, but they received supplementation with biscuits for one-month consumption after the end of study. In the SQ-LNS group, infants received SQ-LNS $20 \mathrm{~g}$ per day in 1 sachet (energy $\sim 118 \mathrm{kcal}$, protein, essential fat acid, 22 vitamins and minerals) for six months. SQ-LNS were provided by Nutriset SAS (Malaunay, France). In another treatment group, infants received biscuits in 3 pieces per day @30 g (energy $\sim 35 \mathrm{kcal}$, protein, 16 vitamins, and minerals) for six months. The biscuit was donated by Ministry of Health, Indonesia and was developed for a national supplementary feeding program. The energy and nutrient contents of a daily ration SQ-LNS and biscuit was reported in the previous article [12]. The child's caregiver was advice to feed mixed in complementary food and divided into two daily doses (@ $10 \mathrm{~g})$.

SQ-LNS and biscuit were delivered by a field team to home respondents' every month for six- month's intervention period. The field team distributed 30 sachets of SQ-LNS or 8 packages of biscuits (96 pieces) per infant and collected information on the use and possible complaints or adverse events. The field team distributed 30 sachets LNS or 8 package biscuit (96 pieces) per infants and collect information on the use and possible complaint or adverse events.

\section{Sources of data}

The primary variable in the study was the change of hemoglobin concentration, prevalence, and incidence of anemia after 3 months and 6 months intervention.

The other variables were child characteristic (sex, age, nutritional status), maternal characteristic (age, length of education, occupation, nutrition education), and household characteristics (household food security status, household dietary diversity), adherence to SQ-LNS and biscuits and morbidity status.

\section{Participants}

Potentially age-eligible children were identified from infant cohort data from midwives. The inclusion criteria included infant more than 6.0 months of age who had consumed complementary food, resided in the study area, and had the signed informed consent from a legal guardian. The exclusion criteria were severe stunting (LAZ <-3 SD), acute infectious disease (i.e., TBC), the presence of edema, history of peanut allergy, severe illness requiring hospitalization, and concurrent participation in another clinical trial.

The sample size was calculated on the basis expected values of hemoglobin change. In the previous study, the mean 
hemoglobin change $0.88(10.57 \mathrm{~g} / \mathrm{dl}$ and $11.45 \mathrm{~g} / \mathrm{dl})$, [13]. Assuming a standard deviation of 1.35 with a power test of $80 \%$ $(1-\beta=0.84)$ and a $95 \%$ confidence interval with a one-sided test of 1.645. The minimum sample required was 30 infants per group. The total samples are 168 infants for three group based on the calculation sample size with another variable (length gain).

\section{Data Collection}

The child's, maternal, and household characteristics were collected at baseline using a structured questionnaire. The instrument of nutrition knowledge was using a questionnaire, which has with 10 questions on breastfeeding and complementary feeding. Based on validity analysis, using product moment testing showed significant correlations $(\mathrm{p}<0.01)$ and reliability of the instrument to assess nutritional knowledge (Cronbach's alpha $=0.222$ ). Household category based on food security status was assessed using nine questions on the household's food access [14]. The adherence of SQ-LNS and biscuit and morbidity status was collected at monthly monitoring using questionnaire by field enumerators.

The measurement of blood hemoglobin concentration was using Photometer Hemocue haemoglo-binometer, Angelholm, Sweden) by trained field enumerators at $0,3,6$ months of intervention. The HemoCue ${ }^{\circledR}$ and the cyanmethemoglobin are the methods recommended for uses in surveys to determine the population prevalence of anemia. The HemoCue ${ }^{\circledR}$ is based on the cyanmethemoglobin methods and can be fix since be stable and durable in field setting [15]. The prevalence and incidence of anemia $(\mathrm{Hb}<11$ $\mathrm{g} / \mathrm{dl})$.

\section{Data Management and Analysis}

Multilevel checked by the selfenumerators, other field workers, and field supervisors were done in the field to assurance quality data. Statistical analysis was done using IBM $^{\circledR}$ SPSS $^{\circledR}$, version 20.0 (IBM Corp., NY, USA). Statistical significance was defined as $p<0.05$.

The distribution of data was checked for normality by using KolmogorovSmirnov test and homogeneity of data variance by using Levene test. Adjusted for covariate was performed using Linear Model ANCOVA to compare hemoglobin concentration. A difference in the incidence of anemia was compared with logistic regression adjusting for respective baseline value.

The study was approved by the Ethical Committee of Faculty of Public Health, University of Diponegoro (Certificate No. 146/EC/FKM/2014). Eligible infants were enrolled in the study after collecting informed consent from at least one parent or caregiver.

\section{RESULTS}

Of the 324 infants screened, 269 of them were enrolled. At the end of the study were 67 infants $(24.9 \%)$ dropped out of the study and 34 infants were excluded from data analysis due to age < 6.0 months. Reasons for dropping out were: migration to other areas temporarily $(n=43)$, not receiving supplementation for more than 3 months $(n=18)$, refusal to continue participating in the study due to the child not liking SQ-LNS or biscuits or vomiting $(n=4)$, mother being busy $(n=1)$, and the child having severe illness requiring hospitalization $(n=1)$. The dropout rate among the study groups was not significantly different with $27.4 \%, 27.8 \%$, and $20.2 \%$ for the Control, SQ-LNS, and Biscuit groups, respectively. Potential biases associated with loss to follow-up were assessed.

The flowchart of participation, baseline characteristic, and adherence to SQLNS and Biscuit as well as morbidity status have presented in the previous article [12]. 
The adherence of SQ-LNS and biscuit and associated factors have been shown in the previous article [16].

\section{Effect of SQ-LNS and Biscuit on Blood Hemoglobin}

At baseline, there was no significant difference between groups for mean $\mathrm{Hb}$ values $(10.27 \mathrm{~g} / \mathrm{dl}, 10.32 \mathrm{~g} / \mathrm{dl}, 10.43 \mathrm{~g} / \mathrm{dl}$ for Control group, SQ-LNS group, and Biscuit group), shown in Table 1. Over 3month intervention period, hemoglobin levels were $9.93 \mathrm{~g} / \mathrm{dl}, 11.05 \mathrm{~g} / \mathrm{dl}, 10.26$ $\mathrm{g} / \mathrm{dl}$ for Control group, SQ-LNS group, and Biscuit group, respectively $(\mathrm{p}=0.018)$. The mean hemoglobin concentration increased significantly by $0.73 \mathrm{~g} / \mathrm{dl}$ in SQLNS group and decreased by $-0.17 \mathrm{~g} / \mathrm{dl}$ in Biscuit group and $-0.34 \mathrm{~g} / \mathrm{dl}$ in Control group.

At the end intervention, over 6month intervention period, hemoglobin levels were $9.98 \mathrm{~g} / \mathrm{dl}, 10.47 \mathrm{~g} / \mathrm{dl}, 10.07$, for Control group, SQ-LNS group, and Biscuit group, respectively $(\mathrm{p}=0.035)$. The mean hemoglobin concentration increaseed by $-0.15 \mathrm{~g} / \mathrm{dl}$ in SQ-LNS group and decreased by $-0.36 \mathrm{~g} / \mathrm{dl}$ in Biscuit group and $-0.29 \mathrm{~g} / \mathrm{dl}$ in Control group.

\section{Effect of SQ-LNS and Biscuit on Prevalence Anemia}

There was no significant difference in the prevalence of anemia at baseline, after the 3-month and 6- month intervention periods $(p>0.05)$, Table 2. At baseline, participants in Control group (63.3\%) had the prevalence of anemia was lower than SQ-LNS (79.5\%) and Biscuit group $(75.5 \%)$, ( $>>0.05)$.

Over three-month intervention period, the significant hemoglobin level greater and resulted in the lowest prevalence of anemia in SQ-LNS with $60.0 \%$, compared with $80.0 \%$ of children in Biscuit group and $87.5 \%$ in Control group. Prevalence of anemia in SQ-LNS de- creased by 19.5 percentage point, whereas in Biscuit and Control group increased to $24.2 \%$ and $15.5 \%$, respectively, Figure 1. Compared to the control, children in SQLNS group had a relative risk (RR) $(95 \%$ CI) of $0.21(0.04-1.30, p=0.095)$ of being anemia at 3-month intervention. Meanwhile, in Biscuit group had an RR of being anemia was $0.57 \quad(0.07-4.87$, $\mathrm{p}=0.609$ ).

At the end of the study, the significant hemoglobin level greater and resulted in the lowest prevalence of anemia in SQ-LNS with $73.9 \%$, compared $93.3 \%$ of children in Biscuit group and $83.3 \%$ in Control group. Over 6-month intervention, the prevalence of anemia in SQ-LNS decreased by 5.6 percentage point, whereas in Biscuit and Control group increased to $17.8 \%$ and $20.0 \%$, respectively. Compared to the control, children in SQ-LNS group had a relative risk (RR) $(95 \% \mathrm{CI})$ of $0.57(0.19-1.66, \mathrm{p}=0.310)$ of being anemia at 6-month intervention. Meanwhile, in Biscuit group had a RR of being anemia was $2.80(0.65-12.09, \mathrm{p}=0.168)$.

\section{Effect of SQ-LNS and Biscuit on Incidence Anemia}

The incidence of anemia over 3month intervention period was 40 events (4/10), 0, and 20.0 events $(2 / 10)$ in Control group, SQ-LNS group, and Biscuit group. The incidence of anemia over 6month intervention period was 34.8 events (8/23), 10.0 events (3/30), and 27.9 events (12/43) in Control group, SQ-LNS group, and Biscuit group.

A provision SQ-LNS resulted in $100 \%(\mathrm{p}=0.011)$ reduction in the incidence of anemia after 3-months intervention period and $79 \%(\mathrm{p}=0.029)$ after 6months intervention. In Biscuit group, thus resulted in $63 \%(\mathrm{p}=0.342)$ reduction in incidence anemia after 3-months intervention and $27 \%(\mathrm{p}=0.565)$ after 6months intervention period. 
Table 1. The hemoglobin concentration among participants by study group

\begin{tabular}{lcccc}
\hline \multicolumn{1}{c}{ Outcomes } & Control & SQ-LNS & Biscuit & p-value \\
\hline $\begin{array}{l}\text { Hemoglobin, g/dl } \\
\text { Baseline }\end{array}$ & $10.27 \pm 1.06$ & $10.32 \pm 0.86$ & $10.43 \pm 1.30$ & 0.806 \\
& $(95 \%$ CI: $9.87-10.67)$ & $(95 \%$ CI: $10.04-10.60)$ & $\begin{array}{c}(95 \% \text { CI: } 10.07- \\
10.79)\end{array}$ & \\
& & & $10.26 \pm 1.02^{\mathbf{a}}$ & 0.018 \\
$\begin{array}{l}\text { Mid } \\
\text { intervention }\end{array}$ & $9.93 \pm 0.86^{\mathbf{a}}$ & $11.05 \pm 1.26^{\mathbf{b}}$ & & \\
& & & & \\
End & $95 \%$ CI: $9.47-10.38)$ & $(95 \%$ CI: $10.35-11.75)$ & $(95 \%$ CI: $9.53-10.99)$ & \\
& $(95 \%$ CI: $9.65-10.31)$ & $(95 \%$ CI: $9.89-10.25)$ & $(95 \%$ CI: $9.89-10.25)$ & \\
& & $10.47 \pm 1.09^{\mathbf{b}}$ & $10.07 \pm 0.60^{\mathbf{a}}$ & 0.035 \\
\end{tabular}

SQ-LNS: small-quantity lipid-based nutrient supplement.

Data are mean \pm SD. Values in the same row with different superscript letters are significantly different $(\mathrm{p}<0.05)$.

Analysis with ANOVA adjusted for baseline

Table 2. Point prevalence and incidence anemia among participants by study group

\begin{tabular}{ccccc}
\hline Outcomes & Control & SQ-LNS & Biscuit & P-value \\
\hline Point Prevalence Anemia & & & & \\
Baseline & $63.3 \%$ & $79.5 \%$ & $75.5 \%$ & 0.297 \\
RR (95\% CI) & $1.0(\mathrm{ref})$ & $2.24(0.77-6.57)$ & $1.78(0.67-4.70)$ & \\
Midline & $87.5 \%$ & $60.0 \%$ & $80.0 \%$ & 0.191 \\
RR (95\% CI) & $1.0(\mathrm{ref})$ & $0.21(0.04-1.30)$ & $0.57(0.07-4.87)$ & \\
Endline & $83.3 \%(30)^{\mathbf{a}, \mathbf{b}}$ & $73.9 \%(34)^{\mathbf{b}}$ & $93.3 \%(42)^{\mathbf{a}}$ & 0.045 \\
RR (95\% CI) & $1.0(\mathrm{ref})$ & $0.57(0.19-1.66)$ & $2.80(0.65-12.09)$ &
\end{tabular}

\section{Incidence Anemia}

\section{3-months follow up}

Ever developed anemia

$$
\begin{aligned}
& 40.0^{\mathrm{a}} \\
& 1.0 \text { (ref) }
\end{aligned}
$$$$
0^{\mathbf{b}}
$$$$
20.0^{\mathbf{a}, \mathbf{b}}
$$$$
0.039
$$$$
\mathrm{RR}(95 \% \mathrm{CI})
$$$$
0
$$$$
0.37(0.38-0.05)
$$

Ever developed

$$
30.0
$$

0

10.0

0.078

moderate anemia 


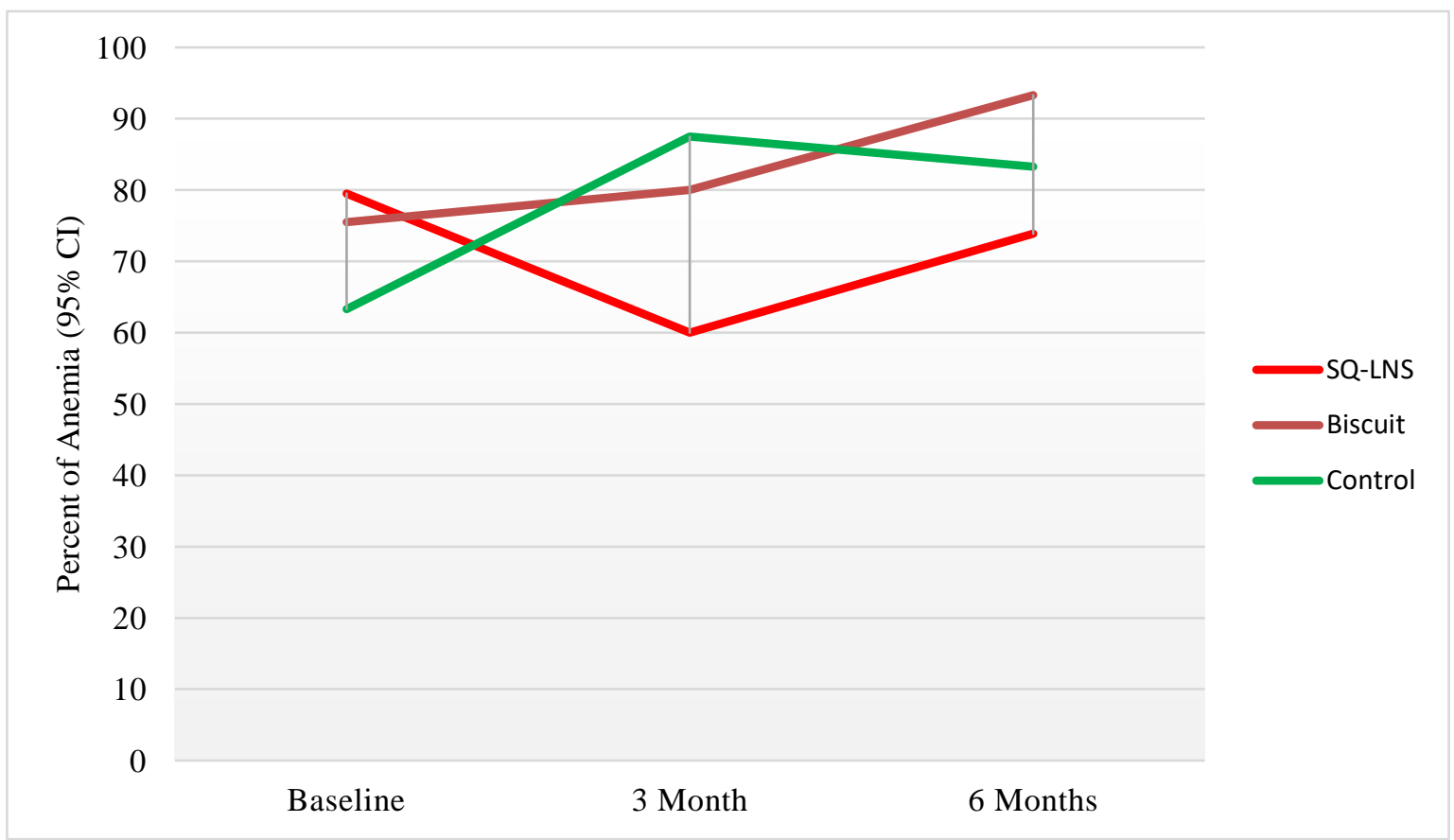

Figure 1. Change in anemia status between 3 month and 6 months intervention

\section{DISCUSSION}

The study was carried out to study the effect of a daily provision smallquantity lipid-based nutrient supplement on hemoglobin concentration and reducing anemia. We compared the effect on biscuit developed by Minister of Health for supplementary food program. The interventions of complementary food supplement are small-quantity lipid-based nutrient supplement with $20 \mathrm{~g}$ daily portion and biscuit with 3 pieces $(30 \mathrm{~g})$ daily portion.

Prevalence of anemia was more than $50 \%$ in all study groups at baseline and confirmed that anemia is the major public health problem in infants and young children in Indonesia. That was in accordance with data from another study showing an anemia prevalence of $58.4 \%$ among infants 6-11 months and $42.6 \%$ among children 12-23 months of age [3]. The data showed that an intervention was needed for infant and childhood to combat anemia.

The provision small-quantity lipidbased nutrient supplement with $20 \mathrm{~g}$ daily doses for children aged 6-12 months showed mean hemoglobin values increased significantly by $0.65 \mathrm{~g} / \mathrm{dl}(\mathrm{p}<0.05)$ after 3 months of intervention. In another study in Peru, the effect of LNS on children aged six to eleven months old increased 0.67 $\mathrm{g} / \mathrm{dl}(\mathrm{p}<0.05),[17]$. Intervention home fortification with micronutrient nutrient powder (MNP) in Dhaka informed that intervention MNP for four-month to children under two years also had significant $2.5 \%$ points enhancement of hemoglobin level [18].

Provision of small-quantity lipidbased nutrition (SQ-LNS) in the study could significant reducing of $19.5 \%$ of proportion anemia and of $100 \%$ of incidence anemia for three-month intervention. Moreover, SQ-LNS can reduce the proportion of anemia by 27 percent point in Peru [17]. In another study, intervention with Nutributer showed reducing prevalence anemia by $22 \%$ for six months intervention [13]. The result of this study has the impact on reducing the prevalence of 
anemia was greater than finding in Dhaka with MNP which statistically significant reduction of $9 \%$ in the 2 months MNP group and $12 \%$ in the 4 months MNP group [18]. The analysis of effect MNP can reduce anemia by $31 \%$ and iron deficiency by $51 \% \%$ in infants and young children [10].

The hemoglobin and vitamin $\mathrm{C}$ content of the daily serving of SQ-LNS was higher than the biscuit. A $20 \mathrm{~g}$ of SQ-LNS per day, provided $6 \mathrm{mg} \mathrm{Fe}$, equal to $85.7 \%$ of recommended dietary allowance (RDA) and $30 \mathrm{mg}$ vitamin $\mathrm{C}$ (60\% of RDA). 3 pieces of biscuit per day, provided $4.8 \mathrm{mg}$ $\mathrm{Fe}(25.7 \%$ of RDA) and no vitamin C.

The strength of the study was similar to characteristic participants and those who dropped out. The distribution and measure of compliance by field team every month and could support the caregiver to regularly giving SQ-LNS or biscuits and also discuss to resolve any adverse events due to consumption of SQ-LNS or biscuits. Trained field team selected with nutrition backgrounds and educations performed the measurement of anthropometric data, interviews using structured questionnaires and conduct a 24-hour recall. The limitations of the study were that the study design was not a randomized control trial because of the different type of product intervention (peanut paste and biscuit), no randomization for allocation of participants; there was no blinding of group allocation and no masking mothers or field workers to who received SQ-LNS or biscuits.

\section{CONCLUSION}

In conclusion, the study showed that small-quantity LNS (SQ-LNS) was more effective in improving hemoglobin level and reducing prevalence and incidence anemia in children 6-12 months over threemonths intervention.

\section{ACKNOWLEDGEMENTS}

We are thankful to the 269 mothers of the participants, to the midwives and nutritionist in 50 villages, and to our field workers for their support and help in the data collection.

The author thanks the entire 'Gizi Sehat' Project team (Nurul Muslihah, Ali Khomsan, Dodik Briawan, Hadi Riyadi, Titis Sari Kusuma, Catur Saptaning Wilujeng). Finally, we extend our sincere appreciation to Neys-Van Hoogstraten Foundation for funding the research (grant IN 259) and Ministry of Health, Republic Indonesia for supporting Biscuit 'MP-ASI' and Nutriset SAS (malaunay, France) for supporting SQ-LNS.

The authors declare that they have no conflicts of interest to declare. This paper is a part of the doctoral dissertation of NM at Bogor Agricultural, University

\section{REFERENCES}

1. Stevens GA, Finucane MM, De-Regil LM, Paciorek CJ, Flaxman SR, Branca $\mathrm{F}$, et al. Global, regional, and national trends in haemoglobin concentration and prevalence of total and severe anaemia in children and pregnant and non-pregnant women for 1995-2011: a systematic analysis of populationrepresentative data. Lancet Glob Heal. 2013;1(1):e16-25.

2. MOH. National Report of Research on Basic Health 2013. Jakarta: Board of health Research and Development; 2013.

3. Muslihah N. Study on husehold food insecurity and impacts on child feeding practices, stunting, anemia of children 6-23 months in poor rural, Indonesia. 2014.

4. Benoist B de, McLean E, Egll I, Cogswell M. Worldwide prevalence of anaemia 1993-2005: WHO global database on anaemia. Worldw Preval anaemia 1993-2005 WHO Glob database anaemia. 2008; 
5. Haas JD, Brownlie T. Iron deficiency and reduced work capacity: a critical review of the research to determine a causal relationship. J Nutr. 2001;131(2):676S-690S.

6. Balarajan Y, Ramakrishnan U, Özaltin E, Shankar AH, Subramanian S V. Anaemia in low-income and middleincome countries. Lancet. 2012;378(9809):2123-35.

7. Joint FAO, Organization WH. Vitamin and mineral requirements in human nutrition. 2005;

8. Dewey KG, Vitta BS. Strategies for ensuring adequate nutrient intake for infants and young children during the period of complementary feeding. Washingt Alive Thrive. 2013;7.

9. Vitta BS, Dewey KG. Identifying Micronutrient Gaps in the Diets of Breastfed 6-11-Month-Old Infants in Bangladesh, Ethiopia and Viet Nam Using Linear Programming. Washington, DC Alive Thrive. 2012;

10. De-Regil LM, Suchdev PS, Vist GE, Walleser S, Pena-Rosas JP. Home fortification of foods with multiple micronutrient powders for health and nutrition in children under two years of age (Review). Evid Based Child Heal [Internet]. 2013/07/24. 2013;8(1):112-201. Available from: http://www.ncbi.nlm.nih.gov/pubmed/ 23878126

11. Arimond M, Zeilani M, Jungjohann S, Brown KH, Ashorn P, Allen LH, et al. Considerations in developing lipidbased nutrient supplements for prevention of undernutrition: Experience from the International Lipid-Based Nutrient Supplements (iLiNS) Project. Matern Child Nutr. 2015;11:31-61.

12. Muslihah N, Khomsan A, Briawan D, Riyadi H. Complementary food supplementation with a small-quantity of lipid-based nutrient supplements prevents stunting in 6-12-month-old infants in rural West Madura Island, Indonesia. Asia Pac J Clin Nutr. 2016 Dec;25(Suppl 1):S36-42.

13. Adu-Afarwuah S, Lartey A, Brown $\mathrm{KH}$, Zlotkin S, Briend A, Dewey KG. Home fortification of complementary foods with micronutrient supplements is well accepted and has positive effects on infant iron status in Ghana. Am J Clin Nutr. 2008 Apr;87(4):92938.

14. Coates J, Swindale A, Bilinsky P. Household Food Insecurity Access Scale (HFIAS) for measurement of food access: indicator guide. Washington, DC Food Nutr Tech Assist Proj Acad Educ Dev. 2007;

15. Organization UNWH. Iron Deficiency Anaemia: Assesment, Prevention and Control: a Guide for Programme Managers. World Health Organization; 2001.

16. Muslihah N, Khomsan A, Briawan D, Riyadi H. Kepatuhan konsumsi suplemen gizi berbasisi lipid dosis kecil pada bayi di perdesaan, Kabupaten Bangkalan. J Gizi dan Pangan. 2016;11(2).

17. Vargas-Vásquez A, Bado R, Alcázar L, Aquino O, Rodríguez A, Novalbos JP. Efecto de un suplemento nutricional a base de lípidos en los niveles de hemoglobina e indicadores antropométricos en niños de cinco distritos de Huánuco, Perú. Rev Peru Med Exp Salud Publica. 2015;32(2):237-44.

18. Mahfuz M, Alam MA, Islam MM, Mondal D, Hossain MI, Ahmed AMS, et al. Effect of micronutrient powder supplementation for two and four months on hemoglobin level of children 6-23 months old in a slum in Dhaka: a community based observational study. BMC Nutr. 2016;2(1):21. 